Research Article

\title{
Examining the Mediating Role of Innovativeness on the Relationship between Innovation Strategy, Atmosphere, Culture and Performance of Hotel Industry in Thailand: A Pilot Study
}

\author{
Thienchai Phankhong*, Lily Julienti Abu Bakar and Donny Abdul Latief Poespowidjojo \\ School of Business Management, Universiti Utara Malaysia (UUM), Kedah, Malaysia \\ thienchai @uum.edu.my; julienti@uum.edu.my; donny@uum.edu.my \\ *Correspondence: thienchai@ @uum.edu.my
}

Received: $2^{\text {nd }}$ January 2020; Accepted: $13^{\text {th }}$ April 2020; Published: $1^{\text {st }}$ May 2020

Abstract: Pilot study is an essential initial step of a survey. The paper aims to explore the validity and reliability of the instrument in the pilot study stage before implementing large scale study of the mediating role of innovativeness between innovation strategy, organizational atmosphere, organizational culture and hotel performance in Thailand. The data were collected from 60 three to five stars hotel in Thailand. In this study using PLS-SEM 3.2.8 software for data analysis. The main results of the study found that content validity greater than 0.90 , the cronbach's alpha coefficient value of all the five constructs ranged from 0.747 to 0.928 . Furthermore, the results of the composite reliability were above 0.70 which is acceptable confirmed that the instruments have a good reliability. Additionally, the results confirmed that the instruments were fit to be used for the actual study.

Keywords: Innovativeness; Innovation Strategy; Organizational Atmosphere; Organizational Culture; Hotel Performance

\section{Introduction}

The Travel and Tourism Competitiveness Index or TTCI showed that Thailand was ranked at number 34 in the world and number 3 in the Southeast and Southern Asia in term of attractive hotel accommodation (World Economic Forum, 2017). Thailand had a total 9,489 hotels in 2018 (Tourism Authority of Thailand, 2019). Instead, there are a several of the challenges effecting the hotels in Thailand such as the complaints on quality of service and other standards to the lower and middle level of the hotel (Departments of Trade Negotiations of Thailand, 2017). Moreover, the performance of hotels in Thailand affected by its high operating cost, sale and marketing issues, management issues, employee low skill and lack of information technology and a number of hotel management have a traditional service and not emphasized by using technology and skill labor (Suriyathanin, 2017). 
The ability of the organization to reformation to change and innovate new things is essential in growing all the time. In the business environment is constantly changing as innovation and organizational innovativeness have a significant effect on competitiveness (Oke, 2007) and are considered a major source of economic growth (Porter \& Ketels, 2003; Pivcevic \& Pranicevic, 2012). According to Eveleens (2010) and Kamaruddeen et al. (2012), key factors purported to influence organizational performance can be identified. They are innovation strategy, organizational culture, and organizational atmosphere. However, in the current study argues that the effect of these factors on organizational performance could be understood by considering innovativeness for the following reasons. In filling the gap, the integrated model of innovativeness will be tested in the hotel industry for the following reasons. Firstly, the hotel industry, as mentioned earlier, is one of the key contributors to the Thailand economy. Secondly, in studying intangible resources based on main theoretical the resource-based view (RBV) and dynamic capabilities (DC) related to firm performance, several researchers have emphasized the manufacturing industry (e.g., Leonidou et al., 2012; Lin \& Wu, 2014; Nieves et al., 2015). The hotel industry seems to have been neglected (Omerzel, 2015).

Due to the facts that the increasing number of tourists, the accommodation investment has accelerated so much so that the price of the rooms is declining. The impact from the sharing economy and the arrival of competitive renewable products, for instance, apartment, condominiums, homestays as well as a budget hotel, have further contributed to the lower prices (Lunkam, 2017). Due to the increasing competition in the accommodation sector, Thailand hoteliers should consider changing their strategy and capability to sustain a competitive advantage to survive in a rapidly changing external environment.

Pilot test is an essential initial step of a survey, which generally is conducted before implementing a full-fledged study (Hazzi \& Maldaon, 2015). The objective of a pilot test is to identify flaws in the variables' operationalization, avoid problems during actual data collection, reduce measurement error as well as ensure the instrument is not ambiguous and easily understood (Sekaran, 2005; Lavrakas, 2008; Hazzi \& Maldaon, 2015). A pilot study methodological including validity and reliability (Hazzi \& Maldaon, 2015). The important reason for evaluating the reliability of a measurement tool because an unreliable tool will adversely affect the results of the study. Reliability is the degree of stability and consistency of an instrument when used repeatedly (Bhattacherjee, 2012). Kumar (2011) defined validity as the degree or the ability of a measurement instrument to measure the things it is supposed to measure. According to Pasunon (2015), ascertaining the validity of a questionnaire consists two main considerations, namely (a) the suitability of the questionnaire in terms of data collection, and (b) checking if the questionnaire is based on concepts and theories.

The assessment of content validity is done through the opinions of expert panels (Crano \& Brewer, 2002). In this study, the researcher will use the content validity index (CVI) measured on a four-point scale for content validity assessment (Polit \& Beck, 2006). A CVI that is more than 0.75 suggests acceptable content validity. To ascertain the reliability of the instruments, this study will use Cronbach's alpha coefficient (Sekaran, 2005) and composite reliability (CR). George \& Mallery (2003) and Hair et al. (2014) suggested that Cronbach's alpha values greater than 0.70 indicate acceptable internal consistency and CR should be greater than 0.70 . Therefore, to confirm the validity and reliability of the instrument, this paper presents the result of pilot test about determinants of organizational performance of three to five hotel industry in Thailand.

\section{Literature Review}

\subsection{Organizational Performance}

Organizational performance refers to an overall concept used to display the overall outcome of the operational activities of an organization ( $\mathrm{Wu} \& \mathrm{Lu}, 2012)$. Organizational performance gauged by financial indicators and non-financial indicators to measure whether the organization to perform the right thing with 
the right approach (Hilman \& Kaliappen, 2014). Kaplan and Norton (1992) developed and proposed the Balanced Scorecard (BSC) for measure organizational performance. The BSC emphasizes four perspectives which are financial perspective, customer perspective, process perspective, and learning and growth. Avci et al. (2011) suggested that BSC could be a forefront measurement appropriated for the service sector, because in this sector most performance measures focus on non-financial, such as customer satisfaction, employee satisfaction, and internal process efficiency.

\subsection{Innovation Strategy (IS)}

Innovation in general has a deeper explanation towards organizational performance (c.f., Ahmed, Shah, Qureshi, Shah \& Khuwaja, 2018). Innovation strategy as a sum of strategic choices regarding its innovation activity for developing new service, process, creation approaches, finding new markets, the source of supply and managerial structure to improve its performance (Wang \& Ahmed, 2004; Strecker, 2009 and Gilbert, 1994). It is generally acknowledged that IS essential to the effectiveness and affect to sustain competitive advantage of the hotel industry (Jenssen \& Randoy, 2006; Crespell \& Hensen, 2008 and Iplik et al., 2014). Likewise, IS can help the hotel to improve service quality, customer satisfaction and increases the level of innovation within the hotel (Lendel \&Varmus, 2011). Numerous scholars found that IS had a positive effect on organizational performance (Nybakk \& Jenssen, 2012; Chunnapiya, 2012; Altuntas et al., 2013; Kitsios \& Sindakis, 2014 and Hilman \& Kaliappen, 2015).

\subsection{Organizational Atmosphere (OA)}

The organizational atmosphere motivates the employees in order to achieve both individual and organizational performance objectives (Bharthvajan, 2014; Adeoye, 2014 and Akbaba, 2016). According to Amabile (1997), personal level of motivation depends on OA and an appropriate OA for innovation encourages and support to employee creative idea and innovative efforts are valued (Shanker et al., 2017). Furthermore, OA can improve implementation of ideas for greater organizational innovation and more general benefits such as employee and consumer satisfaction and perceived service effectiveness (Aarons \& Sommerfeld, 2012). Similarly, Subramaniam (2005) suggested that if the hotel industry wants to employees to be creative and innovative, the organization needs to improve atmosphere that fosters creativity and innovation. Therefore, executives or supervisors should know the art of managing OA. Most studies found a positive relationship between OA and organizational performance (Akbaba, 2016; Alharbi, 2017 and Shanker et al., 2017).

\subsection{Organizational Culture}

Many definitions of organizational culture which from different researchers. However, we can define common definitions of OC as a sum of beliefs, norms, attitudes, shared values, practices and behavior patterns that influence virtually of working life (Denison, 1984). OC as an affected from the organizational relationship history and evolved context of the organization in the way that lead employee to do things (Yesil \& Kaya, 2012). In addition, OC also significantly for the organizational performance and plays a role in the morale, employee's productivity, motivate and maintaining a sustainable competitive advantage for the organization (Abdi \& Senin, 2014; Puri \& Bharti, 2015; Nuansate, 2016; Matinaro \& Liu, 2016 and Warrick, 2017). Hence, the leaders need to know about an effort to develop the culture that aligns organization strategies (Valencia et al., 2010 and Warrick, 2017). Most of the researcher also found that OC positive relationship with hotel industry performance (Wang, 2012; Rahimi \& Gunlu, 2015 and Nuansate, 2016). 


\subsection{Innovativeness}

Innovativeness is an organization's overall innovative capability, receptivity and tendency to change, newness, new ideas, experiment, and innovation to develop a firm's competitive advantage and display innovative behavior constantly over time (Nybakk et al., 2009; Lumpkin, 1996; Wang \& Ahmed, 2004; Hult et al., 2004 and Grawe et al., 2009). Furthermore, innovativeness reflects the degree of an organizational propensity for doing innovation. Consequently, innovativeness can enhance organization competitiveness and reflects a firm's tendency to engage and support new ideas, novelty, experimentation and creative processes (Lumpkin \& Dess, 1996 and Dereli, 2015). Despite there are many method driving the organizational performance, innovativeness has become one of the most widely used methods (Kalmuk \& Acar, 2015). Several past studies also revealed that innovativeness had a positive relationship with organizational performance (Sok et al., 2013; Scholastica \& Maurice, 2013; Leekpai, 2013; Ashraf et al., 2014; Tutar et al., 2015 and Giniuniene \& Jurksiene, 2015).

\section{Methodology}

\subsection{Sample}

A pilot test is a crucial part of a survey, which generally is conducted before implementing a fullfledged study (Hazzi \& Maldaon, 2015). The objective of a pilot test is to identify flaws in the variables' operationalization, avoid problems during actual data collection, reduce measurement error as well as ensure the instrument is not ambiguous and easily understood (Sekaran, 2005; Lavrakas, 2008 and Hazzi \& Maldaon, 2015). According to Baker (1994), the recommended sample size for a pilot study is between 10 and $20 \%$ of the entire sample size to ensure the adequacy of the instrument used. Likewise, Treece and Treece (1982) suggested that the sample size for the pilot study should be $10 \%$ of the sample size. Whereas, Hertzog (2008) suggested that 20 - 25 participants would be efficient and preferable.

Therefore, in this study the sample size consists of 60 three to five-star hotels in Thailand and select the sample used cluster random sampling technique. Firstly, the hotels were grouped into six clusters follow the region zone. Secondly, in determining the number of hotels each cluster use proportionate of each region. Thirdly, was selecting the participants in this survey used simple random sampling. Out of the 60 questionnaires mailed and 42 questionnaires were returned, the response rate was 70 percent and all of them properly filled.

\subsection{Measurement}

The study adapted instruments from previous studies, all the variables used in the study on 5-point Likert scale ranging from strongly disagree to strongly agree. The questionnaire is divided into five sections. The first section is personal background of the respondents. The second section is hotel information. The third section measures the innovation strategy. The fourth section related organizational atmosphere. The fifth section measure the organizational culture. The sixth section measure the innovativeness. The seventh section measure hotel performance. Therefore, table 1 shows the calculation of the instrument's variables in the study (The table 2).

Table 1: Summary of Measurement of the variables

\begin{tabular}{lccl}
\hline Construct & Dimension & Items & \multicolumn{2}{c}{ Sources } \\
\hline Innovation Strategy & Uni & 9 & Terziovski (2010) \\
Organizational Atmosphere & Uni & 6 & Vong et al. (2018) \\
Organizational Culture & Multi & 12 & Denison \& Neale (2000) \\
Innovativeness & Multi & 12 & Wang \& Ahmed (2004) and Grawe et al. (2009) \\
Organizational Performance & Multi & 12 & Wu \& Lu (2012) \\
\hline 5 Constructs & - & $\mathbf{5 1}$ & \\
\hline
\end{tabular}




\section{Validity and Reliability test of the Pilot Study}

\subsection{Validity Results of the Pilot Study}

For suit the target participants, the original items of instrument were back-translation process from English to Thai language and translated back to English by an experienced professional translator. Content validity measures that the appropriateness of the contents or elements of an instrument of a study (Sekaran, 2005). The assessment of content validity is done through the opinions of expert panels (Crano \& Brewer, 2002). Content validity index (CVI) of the instruments was evaluated by three experts in the field of entrepreneurship and hotel management, one expert from the Universiti Utara Malaysia, one expert from Universiti Sains Malaysia and one expert from Thai hotel executive. Table 2 illustrated that the questions 2 items from 51 items were re-phrased for the respondents appropriately and understandable, thereby no item was deleted. The result of content validity that the CVI values of the instrument were greater than 0.90 and to this end, The CVI can evaluate for item-level (I-CVI) and scale-level (S-CVI), I-CVI should be greater than 0.75 and S-CVI should higher 0.90 (Polit \& Beck, 2006). The SmartPLS software version 3.2.8 was employed for testing Cronbach's alpha reliability and composite reliability test of the instrument.

Table 2: Content Validity Index

\begin{tabular}{|c|c|c|c|c|}
\hline Construct & Items of construct & Number of rating 3 or 4 & I-CVI & Interpretation \\
\hline \multirow[t]{9}{*}{ Innovation Strategy } & IS-1 & 2 & 0.67 & Fair \\
\hline & IS-1 & 3 & 1.00 & Excellent \\
\hline & IS-1 & 3 & 1.00 & Excellent \\
\hline & IS-1 & 3 & 1.00 & Excellent \\
\hline & IS-1 & 3 & 1.00 & Excellent \\
\hline & IS-1 & 3 & 1.00 & Excellent \\
\hline & IS-1 & 3 & 1.00 & Excellent \\
\hline & IS-1 & 3 & 1.00 & Excellent \\
\hline & IS-1 & 2 & 0.67 & Excellent \\
\hline \multirow[t]{6}{*}{ Organizational Atmosphere } & OA-1 & 3 & 1.00 & Excellent \\
\hline & OA-2 & 3 & 1.00 & Excellent \\
\hline & OA-3 & 3 & 1.00 & Excellent \\
\hline & OA-4 & 3 & 1.00 & Excellent \\
\hline & OA-5 & 3 & 1.00 & Excellent \\
\hline & OA-6 & 3 & 1.00 & Excellent \\
\hline \multirow[t]{12}{*}{ Organizational Culture } & OC-1 & 3 & 1.00 & Excellent \\
\hline & OC-2 & 3 & 1.00 & Excellent \\
\hline & OC-3 & 3 & 1.00 & Excellent \\
\hline & OC- 4 & 3 & 1.00 & Excellent \\
\hline & OC-5 & 3 & 1.00 & Excellent \\
\hline & OC-6 & 2 & 0.67 & Fair \\
\hline & OC-7 & 3 & 1.00 & Excellent \\
\hline & OC-8 & 3 & 1.00 & Excellent \\
\hline & OC-9 & 3 & 1.00 & Excellent \\
\hline & OC-10 & 3 & 1.00 & Excellent \\
\hline & OC-11 & 3 & 1.00 & Excellent \\
\hline & OC-12 & 3 & 1.00 & Excellent \\
\hline \multirow[t]{6}{*}{ Innovativeness } & IN-1 & 3 & 1.00 & Excellent \\
\hline & IN-2 & 3 & 1.00 & Excellent \\
\hline & IN-3 & 3 & 1.00 & Excellent \\
\hline & IN-4 & 3 & 1.00 & Excellent \\
\hline & IN-5 & 3 & 1.00 & Excellent \\
\hline & IN-6 & 3 & 1.00 & Excellent \\
\hline
\end{tabular}




\begin{tabular}{ccccc}
\hline Construct & Items of construct & Number of rating 3 or 4 & I-CVI & Interpretation \\
\hline & IN-7 & 3 & 1.00 & Excellent \\
IN-8 & 3 & 1.00 & Excellent \\
IN-9 & 3 & 1.00 & Excellent \\
IN-10 & 3 & 1.00 & Excellent \\
& IN-11 & 3 & 1.00 & Excellent \\
Organizational Performance & IN-12 & 3 & 1.00 & Excellent \\
& OP-1 & 3 & 1.00 & Excellent \\
& OP-2 & 3 & 1.00 & Excellent \\
& OP-3 & 3 & 1.00 & Excellent \\
& OP-4 & 3 & 1.00 & Excellent \\
& OP-5 & 3 & 1.00 & Excellent \\
OP-6 & 3 & 1.00 & Excellent \\
OP-7 & 3 & 1.00 & Excellent \\
OP-8 & 3 & 1.00 & Excellent \\
OP-9 & 3 & 1.00 & Excellent \\
& OP-10 & 3 & 1.00 & Excellent \\
OP-11 & 3 & 1.00 & Excellent \\
OP-12 & 3 & 1.00 & Excellent
\end{tabular}

Note. I-CVI = item-level content validity index, S-CVI/Ave = scale-level content validity index, averaging calculation method, S-CVI/UA $=$ scale-level content validity index, universal agreement calculation method.

\subsection{Reliability Results of the Pilot Study}

The result from table 3 and figure 1 using PLS 3.2.8, the reliability from table 2 indicated that Cronbach's alpha coefficient value of all the five constructs was ranged from 0.747 to 0.928 . Specifically, hotel performance has a value of 0.928 , innovation strategy 0.899 , organizational atmosphere 0.795, organizational culture 0.887 and innovativeness 0.885 . Furthermore, the results of the composite reliability were tested indicated that hotel performance has a value of 0.938 , innovation strategy 0.919 , organizational atmosphere 0.855 , organizational culture 0.908 and innovativeness 0.906 . According to Hair et al. (2017) the composite reliability criterion, higher values indicate higher levels of reliability. For instance, we can consider values between 0.60 and 0.70 as "acceptable in exploratory research," whereas results between 0.70 and 0.95 represent "satisfactory to good" reliability levels. Therefore, a measure of internal consistency reliability follows the result of the reliability and composite reliability above 0.70 , which is acceptable confirmed that the instruments have a good reliability.

Table 3: Reliability Test Results

\begin{tabular}{lccc}
\hline \multicolumn{1}{c}{ Constructs } & $\begin{array}{c}\text { Number } \\
\text { of Items }\end{array}$ & Cronbach's alpha & $\begin{array}{c}\text { Composite } \\
\text { Reliability (CR) }\end{array}$ \\
\hline Innovation Strategy & 9 & 0.899 & 0.919 \\
Organizational Atmosphere & 6 & 0.795 & 0.855 \\
Organizational Culture & 12 & 0.887 & 0.908 \\
$\quad$ Adaptability & 3 & 0.747 & 0.855 \\
Consistency & 3 & 0.708 & 0.834 \\
Involvement & 3 & 0.809 & 0.887 \\
Mission & 3 & 0.779 & 0.872 \\
Innovativeness & 12 & 0.885 & 0.906 \\
Service Innovativeness & 3 & 0.799 & 0.883
\end{tabular}




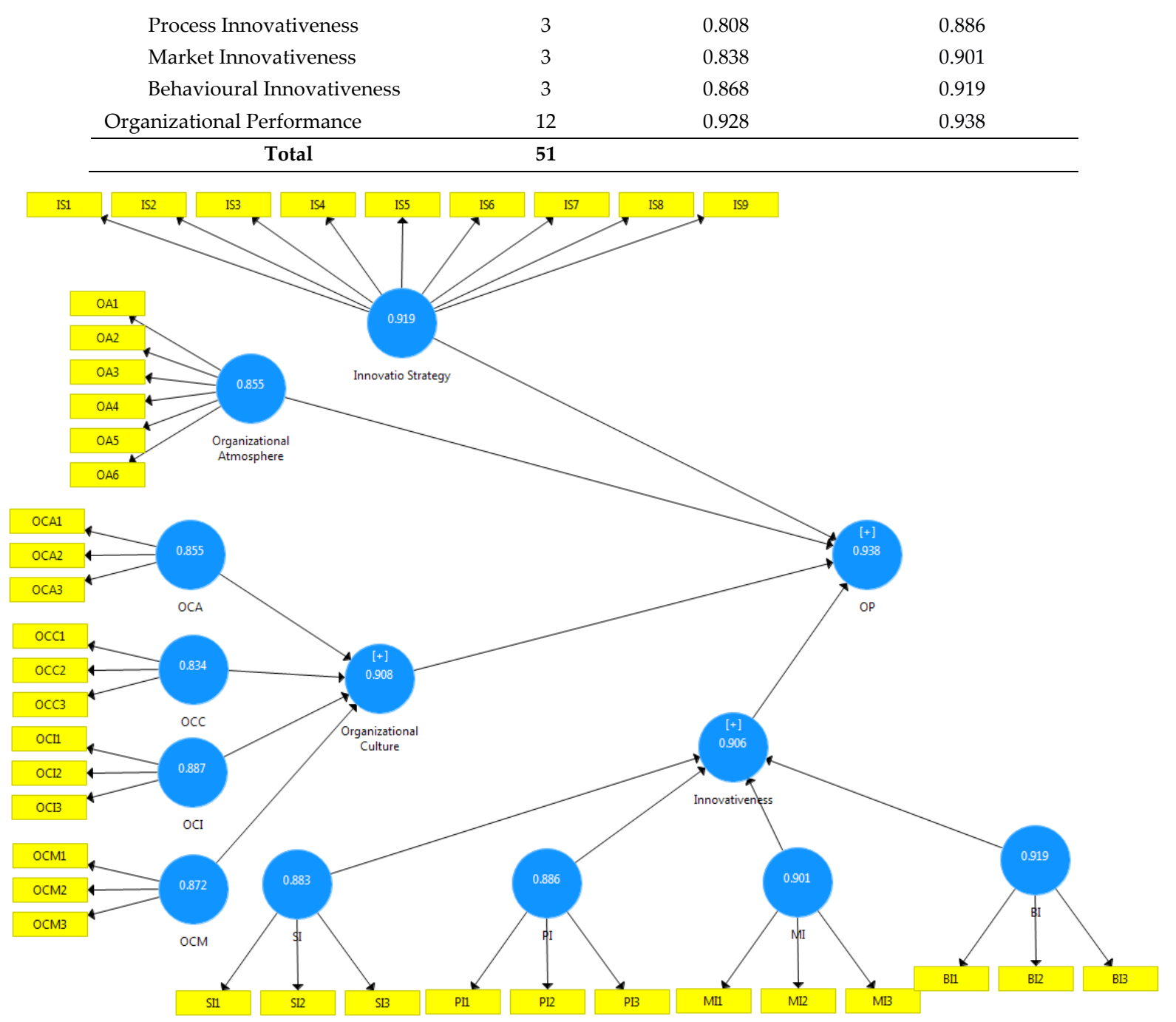

Figure 1: The composite reliability of the pilot study

\section{Conclusion}

As stated earlier, the aims of the pilot study that explored the validity and reliability of the instrument in the smaller scale before implementing large scale study. The results of the pilot test summarized that content validity greater than 0.90 , the cronbach's alpha coefficient value of all the five constructs was ranged from 0.747 to 0.928 . Furthermore, the results of the composite reliability were above 0.70 which is acceptable confirmed that the instruments have a good reliability (Hair et al., 2017). Additionally, according to earlier results confirmed that the instruments were fit to be used for the actual study.

\subsection{Contribution}

The contributions of the study offers clarity to ensure that the validity and reliability of the instrument will be appropriate to the further actual research. Furthermore, the main aims of this study it will expand the knowledge and the complexity of innovativeness in the hotel industry in various aspects. Based on the RBV, IS, OA and OC which are crucial intangible resources to firm's competitive advantage. This study will consider seeking the new approach for enhancing the value add for all resources for gaining competitive advantage, especially innovativeness. Thus, this study will investigate the mediating role of innovativeness between the three variables and performance in the hotel industry in Thailand. 
Practically, the finding of this study will support to the government and the relevant organizations in proposing policies related to improving and developing hotel industry performance in Thailand. In addition, the finding will help the top management of the three to five-star hotels to better understanding the key factors that should be encouraged in order to improve firm performance.

\section{References}

Aarons, G. A., \& Sommerfeld, D. H. (2012). Leadership, innovation climate, and attitudes toward evidence-based practice during a statewide implementation. J Am Acad Child Adolesc Psychiatry, 51(4), 423-31.

Ahmed, U., Shah, S. A., Qureshi, M. A., Shah, M. H., \& Khuwaja, F. M. (2018). Nurturing innovation performance through corporate entrepreneurship: The moderation of employee engagement. Studies in Business and Economics, 13(2), 20-30.

Abdi, K. \& Senin, A.A. (2014). Investigation on the impact of organizational culture on organization innovation. Journal of Management Policies and Practices, 2(2), 1-10.

Adeoye, A. O., Kolawole, I. O., Elegunde, A. F., \& Jongbo, O. C. (2014). The impact of organizational climate on business performance in Lagos metropolis. European Scientific Journal, ESJ, 7(26), 36-47.

Akbaba, Ö., \& Altındağ, E. (2016). The effects of reengineering, organizational climate and psychological capital on the firm performance. Procedia-Social and Behavioral Sciences, 235, 320-331.

Alharbi, K. Yusoff, R. Z. \& Al-Matari, E. M. (2017). The moderating effect of organizational climate on the relationship between of Total Quality Management (TQM) on organizational sustainability: the case of the hotel industry in Saudi Arabia. International Business Management. 11(2), 350-356.

Altuntas, G. Semercioz, F. \& Eregez, H. (2013). Linking strategic and market orientations to organizational performance: The role of innovation in private healthcare organizations. Procedia-Social and Behavioral Sciences, 99(6), 413-419.

Amabile, T. M. (1997). Motivating creativity in organizations: On doing what you love and loving what you do. California Management Review, 40(1), 39-58.

Ashraf, G., Kadir, S. A., Pihie, Z. A. L., \& Rashid, A. M. (2014). The mediator role of organizational innovativeness between organizational culture and organizational effectiveness. British Journal of Education, 2(6), 30-54.

Avci, U., Madanoglu, M., \& Okumus, F. (2011). Strategic orientation and performance of tourism firms: Evidence from a developing country. Tourism Management, 32(1), 147-157.

Baker, T.L. (1994), Doing Social research (2nd Edn.), New York: McGraw-Hill Inc.

Bharthvajan, R. (2014). Organizational Culture and Climate. International Journal of Innovative Research in Science, Engineering and Technology. 3 (1), 8870-8874.

Bhattacherjee, A. (2012). Social science research: Principles, methods, and practices.

Chunnapiya, N. (2012). The relative model of Marketing orientation strategy, Marketing innovation strategy and awareness of Marketing environment changes on the improvement of marketing performance in four and five star hotels in Thailand. Suddhiparitad Journal, 26(78), 121-142.

Crano W. D., Brewer, M.B. \& Lac A. (2015). Principles and methods of social research. $3^{\text {rd }}$., Routledge, New York: Taylor \& Francis Group.

Crespell, P. \& Hansen, E. (2008). Work climate, innovativeness and firm performance in the US forest sector: In search of a conceptual framework. Can. J. For. Res., 38, 1703-1715.

Departments of Trade Negotiations of Thailand. (2018, March 7). Service trade negotiations. Retrieved from http://www.thaifta.com/ThaiFTA/Portals/0/tour_pack8_apr57.pdf

Dereli, D. D. (2015). Innovation management in global competition and competitive advantage. Procedia-Social and behavioral sciences, 195, 1365-1370.

Eveleens, C. (2010). Innovation management; a literature review of innovation process models and their implications. Science, 800(2010), 900. 
George, G. S., \& Mallery, P. (2003). SPSS for windows step by step: A simple guide and reference (Vol. 4). Boston: Allyn and Bacon.

Giniuniene, J., \& Jurksiene, L. (2015). Dynamic capabilities, innovation and organizational learning: Interrelations and impact on firm performance. Procedia-Social and Behavioral Sciences, 213, 985-991.

Grawe, S.J., Chen, H. \& Daugherty, P.J. (2009). The relationship between strategic orientation, service innovation, and performance. International Journal of Physical Distribution \& Logistics Management, 39(4), 282-300.

Hair Jr, J. F., Sarstedt, M., Ringle, C. M., \& Gudergan, S. P. (2017). Advanced issues in partial least squares structural equation modeling. Sage Publications.

Hair, J.F., Sarstedt, M., Hopkins, L., \& Kuppelwieser, V. G. (2014). Partial least squares structural equation modeling (PLS-SEM): An emerging tool in business research. European Business Review, 26(2), 106-121.

Hazzi, O. A., \& Maldaon, I. S. (2015). A pilot study: Vital methodological issues. Business: Theory and Practice, 16(1), 5362.

Hertzog, M. (2008). Considerations in determining sample size for pilot studies. Research in Nursing \& Health, 31, 180191.

Hilman, H., \& Kaliappen, N. (2014). Market orientation practices and effects on organizational performance: Empirical insight from Malaysian hotel industry. Sage Open, 4(4).

Hult, G. T. M., Hurley, R. F., \& Knight, G. A. (2004). Innovativeness: Its antecedents and impact on business performance. Industrial Marketing Management, 33(2004), 429-438.

Iplik, F. N., Topsakal, Y. \& Dogan, O. (2014). Strategic innovation: An empirical study on hotel firms operating in Antalya Region. An International Journal of Akdeniz University Tourism Faculty, 2(1), 16-29.

Jenssen J.I. \& Randoy T. (2006). The performance effect of innovation in shipping companies. Maritime Policy \& Management. An International Journal of Shipping and Port Research, 33(4), 3277-343.

Kalmuk, G. \& Acar, A.Z. (2015). The mediating role of organizational learning capability on the relationship between innovation and firm's performance: A conceptual framework. Procedia - Social and Behavioral Sciences, 210, 164169.

Kamaruddeen, A. M., Yusof, N. A., Said, I., \& Pakir, A. H. K. (2012). Organizational factors and innovativeness of housing developers. American Journal of Applied Sciences, 9(12), 1953.

Kaplan, R. S. \& Norton, D.P. (1992). The balanced scorecard: Measures that drive performance. Harvard Business Review, (January-February), 71-79.

Kitsios, F., \& Sindakis, S. (2014, February). Analysis of innovation strategies in hospitality industry: Developing a framework for the evaluation of new hotel services in Thailand. In ICIE 2014 Proceedings of the 2nd International Conference on Innovation and Entrepreneurship: ICIE 2014 (p. 136). Academic Conferences Limited.

Kumar, R. (2011). Research methodology a step-by-step guide for beginners. $3^{\text {rd }}$ Edition. Sage, New Delhi.

Lavrakas, P. J. (2008). Encyclopedia of survey research methods. Encyclopedias. Edited, V.1\&2, A sage reference publication.

Leekpai, P., Jaroenwisan, K., Trichan, C. \& Jirakiattikul, S. (2014). Innovativeness of hotel business in southern Thailand. Journal of Management Science. 31(1), 69-95.

Lendel, V. \& Varmus, M. (2011). Creation and implementation of the innovation strategy in the enterprise. Economics and Management, 16, 819-825.

Leonidou, L.C., Leonidou, C.N., Fotiadis, T.A. \& Zeriti, A. (2013). Resource and capabilities as drivers of hotel environmental marketing strategy: Implications for competitive advantage and performance. Tourism Management, 35, 94-110.

Lin, Y. \& Wu, L. - Y. (2014). Exploring the role of dynamic capabilities in firm performance under the resource-based view framework. Journal of Business Research, 67(2014), 407-413.

Lumpkin, G.T. \& Dess, G.G. (1996). Clarifying the entrepreneurial orientation construct and linking it to performance. The Academy of Management Review, 21(1), 135-172. 
Lunkam, P. (2018, March 7). Trend of industrial/business 2018 - 2020: Hotel business. Krungsri Bank Research. Retrieved from https:/www.krungsri.com/bank/getmedia /9027bab8-d979-4f28-9ff3f21444f5dab1/IO_Hotel_2017_TH.aspxMatinaro, V., \& Liu, Y. (2017). Towards increased innovativeness and sustainability through organizational culture: A case study of a Finnish construction business. Journal of cleaner production, 142, 3184-3193.

Nieves, J., Quintana, A. \& Osorio, J. (2015). Organizational knowledge, dynamic capabilities and innovation in the hotel industry. Tourism and Hospitality Research, 1-14.Nuansate, S. (2016). Synergistic Effect of responsive, proactive market orientation and organizational culture and its impact on hotel overall business performance in Thailand. Doctor of Philosophy Universiti Utara Malaysia.

Nybakk, E. \& Jenssen, J.I. (2012). Innovation strategy, working climate, and financial performance in traditional manufacturing firms: An empirical analysis. International Journal of innovation management. 16(2), 1-26.

Oke, A. (2007). Innovation types and innovation management practices in service companies. International Journal of Operations \& Production Management, 27(6), 564-587.

Omerzel, D.G. (2015). Innovativeness in tourism: Model development. Procedia Economics and Finance, 23, $750-756$.

Pasunon, P. (2015). Validity of questionnaire for social science research. Journal of Social Sciences Srinakharinwirot University, 18(January-December), 375-396.

Pivcevic, S. \& Pranicevic, G.G. (2012). Innovation activity in the hotel sector-the case of Croatia. Economic Research Ekonomska Istrazivanja, 25(1), 337-363.

Polit, D. F., \& Beck, C. T. (2006). The content validity index: Are you sure you know what's being reported? Critique and recommendations. Research in nursing $\mathcal{E}$ health, 29(5), 489-497.

Porter, M.E. \& Ketels, C. (2003). UK competitiveness: Moving to the next stage, DTI Economics Paper No.3.

Puri, R.K. \& Bharti, V. (2015). Effects of organizational culture on innovation: An empirical investigation in software industries (hypothesis development a review). International Journal in Management and Social Science, 3(2), 5671.

Rahimi, R. \& Gunlu, E. (2015). Implementing customer relationship management (CRM) in hotel industry from organizational culture perspective case of a chain hotel in the UK. International Journal of Contemporary Hospitality Management, 28(1), 89-112.

Scholastica, U. \& Maurice, U. (2013). The relationship between market orientation firm, innovativeness and business performance of companies in Nigeria. International Journal of Asian Social Science, 3(11), 2350-2362.

Sekaran, U. (2005). Research methods for business skill building approach: Joh Wiley \& Son.

Shanker, R., Bhanugopan, R., van der Heijden, B. I. J. M., \& Farrell, M. (2017). Organizational climate for innovation and organizational performance: The mediating effect of innovative work behavior. Journal of Vocational Behavior, 100, 67-77.

Sok, P., O'Cass, A. \& Sok, K.M. (2013). Achieving superior SME performance: Overarching role of marketing, innovation, and learning capabilities. Australasian Marketing Journal, 21, 161-167.

Strecker, N. (2009). Literature review. In Innovation strategy and firm performance (pp. 11-67). Gabler.

Subramaniam, R. (2005). A multivariate study of the relationship between organizational learning, organizational innovation and organizational climate in the Australian hotel industry (unpublished doctoral dissertation). Swinburne University of Technology, Australia.

Suriyathanin,W. (2015). Service sector new driving force of Thailand economic. Retrieved $17 \mathrm{~h}$ October 2017 from https://www.bot.or.th/Thai/ResearchAnd Publications/DocLib_/article28_04_58.pdf

Terziovski, M. (2010). Innovation practice and its performance implications in small and medium enterprises (SMEs) in the manufacturing sector: A resource-based view. Strategic Management Journal, 31, 892-902.

Tourism Authority of Thailand, (2019, October 20). Amazing Thailand year 2018. Retrieved from https://thai.tourismthailand.org. 
Treece, E. W., \& Treece, J. W. (1982). Elements of research in nursing (3 ${ }^{\text {rd }}$ ed.). St. Louis, MO:Mosby.

Tutar, H., Nart, S. \& Bingol, D. (2015). The effects of strategic orientations on innovation capabilities and market performance: The case of ASEM. Procedia - Social and Behavioral Sciences, 207, 709-719.

Valencia, N., J. C., Sanz Valle, R., \& Jiménez Jiménez, D. (2010). Organizational culture as determinant of product innovation. European Journal of Innovation Management, 13(4), 466-480.

Vong, L. T. N., Ngan, H. F. B., \& Lo, P. C. P. (2018). Does organizational climate moderate the relationship between job stress and intent to stay?. Journal of Chinese Human Resource Management., 9(1), 2-20.

Wang, C.L. \& Ahmed, P.K. (2004). Culture and climate for innovation. European Journal of Innovation Management, 1(1), 30-43.

Wang, G.L. (2012). A study of how the organizational culture of international tourist hotels affects organizational performance: Using intellectual capital as the mediating variable. The Journal of Global Business Management, 8(1), 189-201.

Warrick, D. D. (2017). What leaders need to know about organizational culture. Business Horizons, 60(3), 395-404.

World Economic Forum, (2017, March, 18). The travel \& tourism competitiveness report 2017. Retrieved from http://www3.weforum.org/docs/WEF_TTCR_2017_web_0401.pdf

$\mathrm{Wu}, \mathrm{S}$. I., \& Lu, C. L. (2012). The relationship between CRM, RM, and business performance: A study of the hotel industry in Taiwan. International Journal of Hospitality Management, 31(1), 276-285.

Yesil, S. \& Kaya, A. (2012). The role of organizational culture on innovation capability: Empirical study. International Journal of Innovation Technology and Business Management, 6(1), 11-25.

(C) 2020 by the author(s). Published by Annals of Contemporary Developments in Management \& HR (ACDMHR), under the terms and conditions of the Creative Commons Attribution (CC BY)

license which can be accessed at http://creativecommons.org/licenses/by/4.0. 